\title{
脳動静脈奇形摘出術の基本戦略
}

\author{
岩間 亨, 吉村 紳一, 矢野 大仁, 大江 直行 \\ 榎本由貴子，山田 清文，高木 俊範
}

\section{Basic Surgical Strategy for Cerebral Arteriovenous Malformations}

Toru Iwama, M.D., Shin-ichi, Yoshimura, M.D., Hirohito Yano, M.D., Naoyuki Ohe, M.D., Yukiko Enomoto, M.D., Kiyofumi Yamada, M.D., and Toshinori Takagi, M.D.

Department of Neurosurgery, Gifu University Graduate School of Medicine, Gifu, Japan

\begin{abstract}
Summary: We describe basic surgical strategy and techniques for resection of cerebral arteriovenous malformations (AVMs). Understanding of the vascular structure of AVMs is important to plan surgical strategies for AVMs. The craniotomy should be large enough as to expose all the structures of the AVMs, such as nidus, feeders and drainers. In the first step of surgery, feeders are secured to control bleeding and to reduce tension of the nidus and drainers. Preoperative occlusion of the hidden feeders by endovascular surgery is a useful option. For an approach to the buried nidus, retrograde dissection of the main drainer is effective. When bleeding is difficult to control during dissection of the nidus, the dissection plane has got into the nidus and should be reset outward. Feeding arteries are coagulated and cut after they are confirmed to contribute to the AVM. The main drainer should be preserved up to the final step of the resection. Intraoperative angiography is useful to identify the feeders and to confirm the residuals of the AVM.
\end{abstract}

\author{
Key words: \\ - arteriovenous malforma- \\ tion \\ - resection \\ - surgical strategy \\ - basic technique
}

Surg Cereb Stroke

(Jpn) 37: 390-394, 2009

\section{はじめに}

脳動静脈奇形 (arteriovenous malformation: 以下 AVM) に対する治療は, 外科的摘出, 定位的放射線治療, 血管内 治療によって, あるいはこれらのモダリティを組み合わせ て複合的に行われている. AVMの部位や大きさ, 症候や 出血の有無などによって個々に治療方針が検討されるが, 現時点での治療指針として Spetzler-Martin 分類 ${ }^{3)}$ の grade 1-3に対しては外科的摘出術が推奨され, 外科手術の危険 性が高く病巣が小さい場合には定位的放射線治療が勧めら れている ${ }^{2)}$.しかし, 実際にAVM 手術の経験を有する脳
神経外科医は必ずしも多くなく，摘出術を比較的安全に行 うことができる場合であっても定位的放射線治療が選択さ れることも多いと思われる. AVM 摘出術の難易度は高い が最も確実な治療手段であることから, 多くの脳神経外科 医がAVM 手術の要点を理解し，手術が適応となる症例に 対しては適切に摘出術が行われるべきであると考えられ る. 本稿では AVM 手術の基本戦略と基本手技についてわ れわれの考えを述べる。

\section{AVM 摘出術の基本戦略}

AVM 摘出術の基本戦略をきわめて単純に表現するなら

岐阜大学大学院医学系研究科 脳神経外科学分野(受稿日 2008.12.22) (脱稿日 2009.3.25)〔連絡先： =501-1194 岐皁市柳戸1-1 岐阜大 学大学院医学系研究科 脳神経外科学分野 岩間 亨] [Address correspondence: Toru IwAMA, M.D., Department of Neurosurgery, Gifu University Graduate School of Medicine, 1-1 Yanagito, Gifu 501-1194, Japan] 

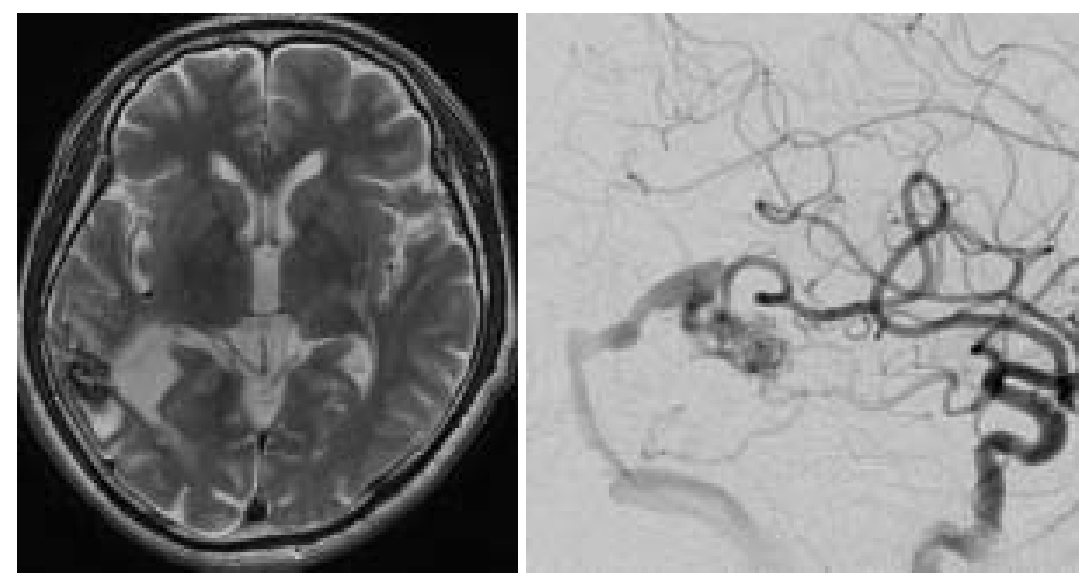

Fig. 1 A: Preoperative T2 weighted MR image demonstrates a flow-void with a highintensity area at the right temporal cortex.

B: Lateral view of the preoperative right carotid angiogram shows a small arte-

$A \mid B$ riovenous malformation ( $A V M)$ ). The $A V M$ is fed by temporal branches of the middle and posterior cerebral arteries, and drained to the transverse sinus via 2 drainers.

ば「主な feeder を確保し，AVMへの血流をコントロー ルしつつ drainer と nidusを周囲脳から剝離し, 順次 feeder と従たる drainer を切断し, 最後に main drainerを切断 してAVMを摘出する」こととなる。

実例を呈示し，具体的な手順とともに，各ステップでの 留意点, 対策を述べる.

\section{症例}

57 歳の男性でてんかん発作にて発症した.MRIにて右 側頭葉に陳旧性の血腫を伴う flow-void が認められた(Fig. 1A)．脳血管撮影 (DSA) にて中大脳動脈 (MCA) と後大脳 動脈 (PCA)の側頭枝を feeder とし横静脈洞へ流出する drainer を有するAVMが確認された(Fig. 1B).

\section{AVM 摘出術}

\section{1. 手術準備}

術中の feederの同定や遮断の確認, 残存 AVM の確認 に術中 DSA はきわめて有用であり ${ }^{1)}$, 原則として必須と 考えるべきである．術中 DSA 対応のカーボン製 Mayfield を用いて頭部を固定しておく.

\section{2. 開頭と硬膜切開}

AVMの摘出にあたっては構成要素である feeder, nidus, drainerの全体像を把握することが重要である。ま た，AVM摘出術では術中になんらかの問題が生じた場合 には著しい脳腫脹をきたす危険性がある。そのため，すべ ての症例で可能ではないが，できる限り術野に feeder， nidus，drainerのすべてが観察でき，かつ十分に大きめの 開頭を行っておくことが望ましい. Fig. 2 に本例の皮切,



Fig. 2 Intraoperative view. U-shape skin incision and craniotomy is drawn on the scalp.

開頭範囲を示す。

流出路となる静脈洞の圧は上昇しており, 開頭時の損傷 に注意する．もし，静脈洞上の硬膜面から出血する場合に は, fibrin glue付きの Surgicelにより十分時間をかけて圧 迫止血する，脳表の AVM ではしばしば硬膜との癒着がみ られる。癒着が強い場合には無理に剝離せず癒着の周囲 で硬膜を切断し AVM側に癒着硬膜を残す。

\section{Feeder の確保と drainer の剥離}

出血のコントロールと nidus, drainerの剝離操作を容 易にするために，最初にfeederの確保を行う。術野内で 確保が困難な feeder は, 血管内治療により予め塞栓して おくとよい. 


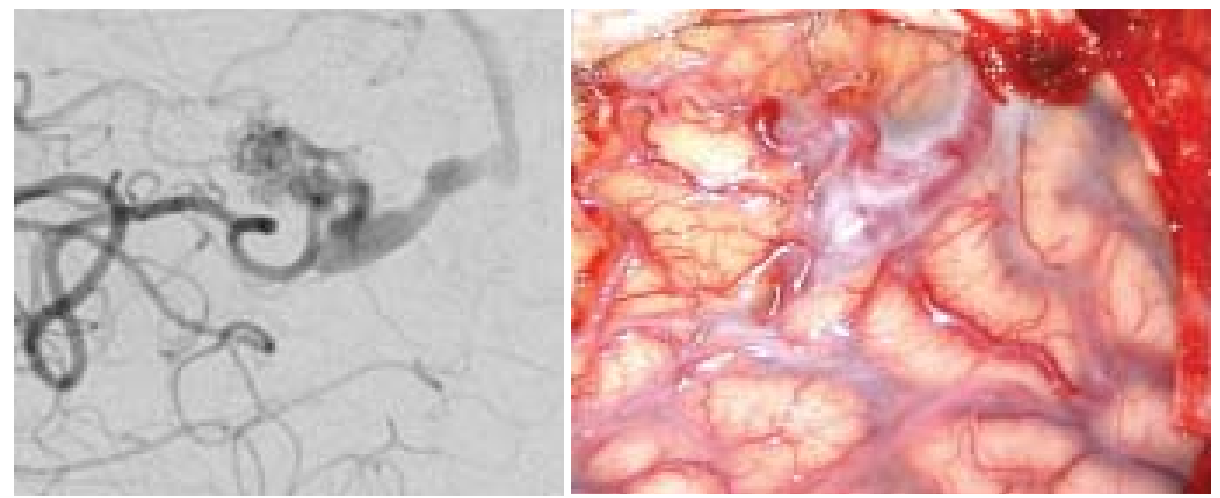

Fig. 3 A: Preoperative angiogram matched with intraoperative view. B: Intraoperative view after dural opening. The main drainer is confirmed through whitened arachnoid membrane.
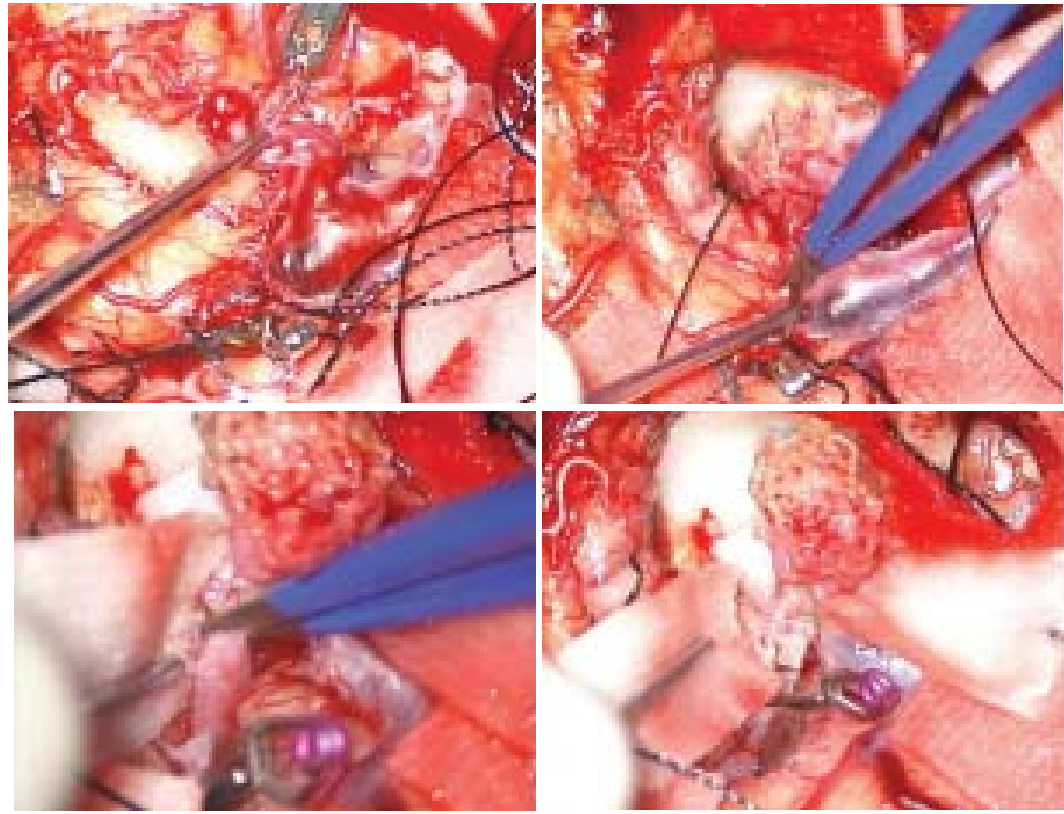

Fig. 4 Intraoperative views.

A: The main feeder and 2 small feeders are clipped to reduce the tension of the AVM. Color of the main drainer is partly turned to dark.

B: The nidus is almost totally dissected. Color of the main drainer is turned

to dark more.

C: The main feeder is coagulated at the final stage of the dissecion.

D: The coagulated main feeder is cut.

Fig. 3 に本例の脳表所見と, 術野に方向を一致させた DSA を示す. 本例はnidusも小さく構造も比較的単純で, 前上方と前下方からそれぞれ MCA, PCAからの feeder が流入し，後方と下方に drainer が存在していた. nidus 前上方の sulcusを開放してMCA からの main feederを確 保したのち, 脳表の drainer周囲のくも膜を全周性に浅 く剝離した. main feeder と PCAからのfeeder と思われ た細血管をクリップにて遮断したのち(Fig. 4A), nidus の剝離を開始した，feederの遮断により，わずかながら drainerの色が暗く変化している。

本例のようにAVM の位置や範囲がわかりやすい例では 問題ないが，症例によってはnidusが脳溝内に存在して脳 表から観察されなかったり，逆に脳表に多数の異常血管が 観察され，nidus本体の範囲がわかりにくい場合には， main drainer を逆行性に剝離していくと確実に nidus 本体 に到達することができる ${ }^{4)}$ ，通常， drainerの壁は肥厚し 

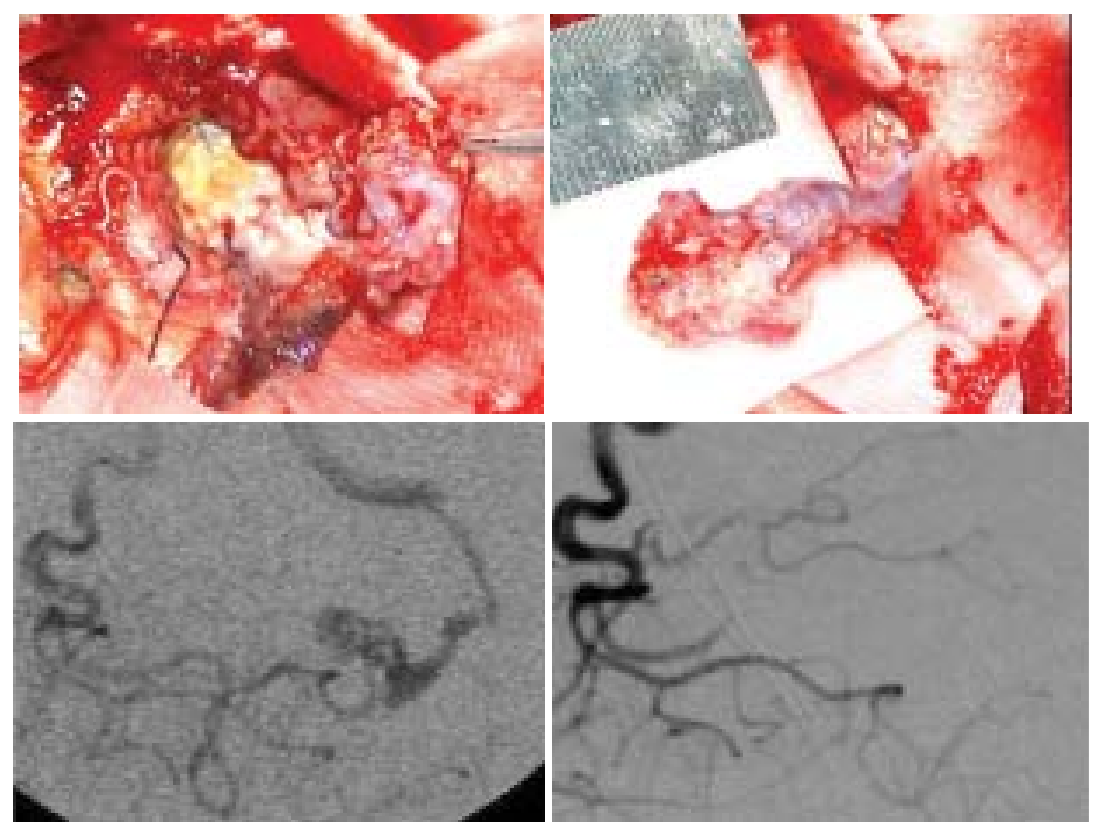

Fig. 5 Intraoperative views.

A: The nidus is lifted up from the cortex.

B: The nidus is completely dissected with connection to the brain by the main drainer.

\begin{tabular}{l|l}
$\mathrm{A}$ & $\mathrm{B}$ \\
\hline $\mathrm{C}$ & $\mathrm{D}$
\end{tabular}

C: Intraoperative control DSA demonstrating the AVM.

D: Intraoperative DSA obtained after resection of the AVM. Disappearance

of the AVM is confirmed.
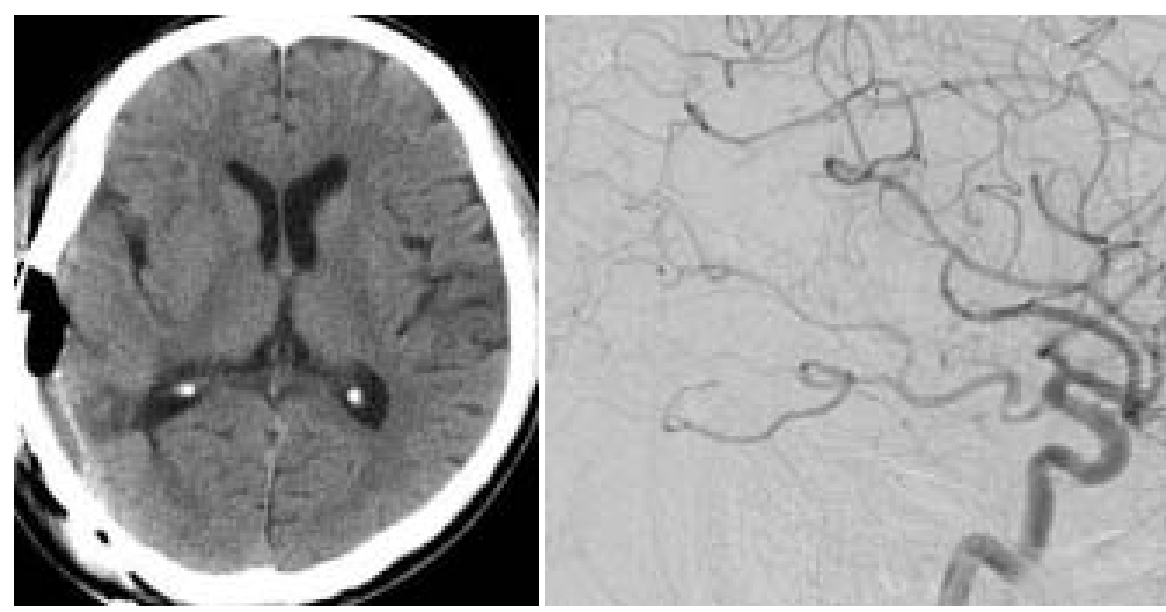

Fig. 6 A: Postoperative CT shows neither bleedings nor infarctions. B: Lateral view of the postoperative right carotid angiogram demonstrates extirpation of the AVM.

ており剝離操作による損傷の危険性は少ないが, tension が低いほうがより安全であり，可能な範囲で feederを遮 断したのちに剝離したほうがよい。もしも損傷した場合 には，凝固せずに Surgicel と fibrin glueによる圧迫止血 を行う.

AVM 周囲の白濁して肥厚したくも膜や drainer の剝離
には血管吻合用の鑷子，剪刀が有用である.

\section{Nidus の剥離}

確実な剝離操作と出血のコントロールのため, nidus の剝離は全周性に浅いところから順次深部に進めるよう に心がけ, 一部分だけ深く剝離を進めることは避ける4). 
feederの中には passing artery としてAVM とともに正 常脳へも灌流している場合があり, 最終的に nidusに入る ことが確実となった時点で凝固切断し，それまではクリッ プによる遮断を行っておく ${ }^{1)}$. drainerもすべてを温存し ながら nidusを剝離することはできない. main drainerは 必ず最後まで温存し, それ以外の drainer は細いものから 順次凝固・切断しつつ剥離を進める.

nidusの辺縁は多数の異常血管のループにより形成され ていることをイメージし，これらの血管を feederや drainer と誤って凝固・切断しないように留意する ${ }^{1)}$. 剝離中 に nidusに切り込んでしまった場合は, 出血のコントロー ルが困難となる。コントロールが困難な出血を生じたら 「nidusに切り达んだ」との認識を持ち, 出血点でむやみ に操作を続けることなく, やや外側の正しい境界で剝離, 止血を行う. nidus辺縁のいわゆる “赤虫”と呼ばれる fragile な血管はバイポーラーによる凝固のみでは弾けて 出血するため, ミニクリップをかけて血管の圧を下げたの ち, バイポーラーの出力を下げて凝固する.

本例では main feeder と main drainerを残してほぼ全周 性に渌離を行ったのち(Fig. 4B), main feederがnidusに 入る直前で凝固・切断した (Fig. 4C, D).

\section{Main drainer の切断と AVM の摘出}

すべての feederが切断されると, nidusの tension が下
がり red veinを呈していた drainerの色が暗くなる。 drainerを十分に凝固して切断し，AVMを摘出する.

本例でも最終的に AVMが main drainerのみで脳と繋 がった状態とし(Fig. 5A，B), main drainerを切断して摘 出した。術後出血の原因となりうる残存 AVMのないこと を術中DSAにて確認し手術を終了した(Fig. 5C, D). Fig. 6 に術後のCT, DSA を示す。

$$
\text { まと め }
$$

単純な血管構築をもつAVMを実例にあげ，AVM 摘出 術の基本的な戦略と手技，各ステップにおける留意点を述 ベた.

\section{文献}

1) Hashimoto N, Nozaki K, Takagi Y, et al: Surgery of cerebral arteriovenous malformations. Neurosurgery 61 (SHC Suppl 1): SHC-375-SHC-389, 2007

2）篠原幸人, 吉本高志, 福内靖男, ほか: 脳動静脈奇形. 脳 卒中治療ガイドライン 2004, 協和企画, 東京, 2004, pp119-122

3) Spetzler RF, Martin NA: A proposed grading system for arteriovenous malformations. J Neurosurg 65: 476-483, 1986

4) Yamada S, Brauer FS, Knierim DS: Direct approach to arteriovenous malformations in functional areas of the cerebral hemisphere. J Neurosurg 72: 418-425, 1990 